\title{
Population Dynamic Consequences of Female Territoriality in Bank Voles ${ }^{1}$
}

\author{
Nils Chr. STENSETH
}

\begin{abstract}
Stenseth N. C., 1985: Population dynamic consequences of female territoriality in bank voles. Acta theriol., 30, 28: 445-460 [With 3 Tables. \& 8 Figs.]

A population dynamic model for Clethrionomys glareolus (Schreber, 1780) is developed and analyzed. The model incorporates the fact that a high number of territorial and mature females inhibits sexual maturation of young females. In addition, density dependence in litter size and in the interval between litter-productions are assumed. Seasonality is also incorporated in the sense that reproduction is assumed only to occur during summer. Analysis of the model demonstrates that the female territoriality is a strongly stabilizing factor. Short reproductive summer seasons and large litters may, however, destabilize these dynamics.

[Dept. of Biology, Division of Zoology, University of Oslo, P.O. Box 1050, Blindern, N-0316, Oslo 3, Norway]
\end{abstract}

\section{INTRODUCTION}

Contrary to several other microtine genera, Clethrionomys constitutes a rather homogeneous group with respect to social organization: all studied populations of any Clethrionomys species seem to be characterized by reproductively active females having exclusive territories (e.g., Bujalska, 1985), whereas males do not have such territories (e.g., Gipps, 1985). Microtus, for example, is far more diverse in this respect (see e.g., Stenseth et al., 1985a). Nevertheless, there are both stable and cyclic populations of Clethrionomys (e.g., Henttonen et al., 1985) just as there are both stable and cyclic populations of Microtus (e.g., Stenseth et al., 1985b). Specifically, we know that the bank vole (C. glareolus) exhibits both stable and cyclic populations (e.g., Petrusewicz, 1983; Henttonen et al., 1985; Stenseth et al., 1985b).

It has been proposed that the exclusive territoriality of reproducing females operates as a stabilizing factor (see, e.g., Bujalska, 1970, 1983a, 1985; Rajska-Jurgiel, 1976; Gliwicz \& Rajska-Jurgiel, 1983). Others have, however, proposed that this territoriality may contribute to the generation of regular cycles (Wiger, 1982). Earlier I have investigated

1 Dedicated to the late Professor Kazimierz Petrusewicz whose studies on the ecology of small rodents in general - and of the bank vole in particular - have greatly improved our understanding of microtine population dynamics. This little man was a great scientist - he was a great man! 
these ideas from a general theoretical point of view (Stenseth et al., 1985a; Stenseth \& Fagerström, 1985; Stenseth \& Antonsen, 1985). Collectively these studies suggested that when disregarding all effects of seasonality, but incorporating effects of habitat heterogeneity (i.e., Stenseth et al., 1985a), territoriality will stabilize the population dynamics; at most, the number of immature individuals will fluctuate slightly. Seasonality and high reproductive rates may, however, destabilize the population dynamics (Stenseth \& Fagerström, 1985).

In this paper I investigate the population dynamic consequences of an idea orginally proposed by Bujalska $(1981,1983 \mathrm{a}, 1985)$ : the proportion of reproductively active females (i.e., those having a breeding territory) will decrease with increasing total density (Fig. 1). By combining this idea with the fact that the summer period is the main reproductive season (e.g., Bujalska, 1983b); I have developed a model for studying the resulting population dynamic patterns. Throughout, I apply the cohort-concept (e.g., Gliwicz et al., 1968; Gliwicz, 1983a, b);

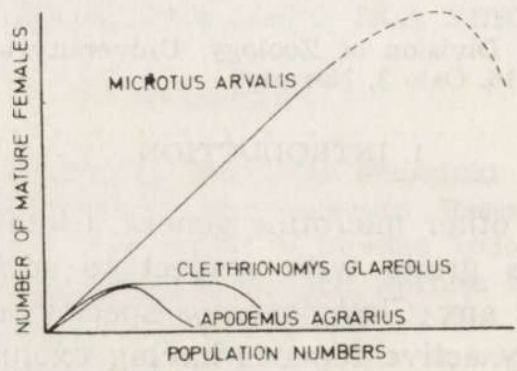

Fig. 1. Three curves describing the relationships between the number of mature adult females and the total population density (after Bujalska, 1981). The mathematical formulae for Clethrionomys and Apodemus are given in the main text (Eqs. (11) \& (12)); the formula for the solid part of the Microtus curve is "Number of mature females" $=-4.19+0.55 \times$ (Total number of females) (Bujalska, 1984; pers. comm.).

that is, I assume that litters are produced fairly synchronously during the summer.

When analyzing the model I search for features tending to stabilize as well as features tending to destabilize the population dynamics. This I do by changing the values of several of the model-parameters. However, in this analysis I am not particularly concerned about whether the resulting population dynamics patterns seen in microtine rodents emerge from the model. This is so because the model disregards a variety of presumably important biological factors (food availability, predators, etc.). It is, however, only by analyzing a model being as simple as possible we can deduce the pure consequences of territoriality. We 
must hence disregard these other potentially important - but complicating - biological aspects.

\section{THE MODEL}

Only females are considered in the model. This is resonable to do for a species where females are territorial: only the availability of territories will limit the population density of mature females - the number of males is presumably always sufficient to inseminate the reproductively active females (for further justification of this see, for example, Stenseth et al. (1985a) and Stenseth \& Fagerström (1985)). For this very reason, the Polish ecologists studying the bank vole (see Petrusewicz, (ed.), 1983) have concentrated on the ecology of $\mathrm{fem}$ a le bank voles.

\subsection{Summer and Winter Periods}

The year, consisting of 365 days, is assumed to be divided into two: one summer period of length $T_{s}$ days, and one winter period of length $\left(365-T_{s}\right)$ days. Reproduction is assumed to be possible only during the summer period. No reproduction is assumed to occur during the winter period (but see Hansson, 1984a; Eriksson, 1985).

Survival of females is assumed to be density-independent; net reproduction - and hence, juvenile survival - is, however, assumed to depend upon density (see below; Eg. (5)). The daily rate of survival, $\boldsymbol{s}_{\boldsymbol{s}}$, during summer, is assumed to be lower than the rate of survival, $s_{w}$, during winter (see, e.g., Petrusewicz et al., 1971; Gliwicz, 1983a, b).

\subsection{Length of Time between Litter Production during the Summer Period}

Considering only the female part of the population, as I do in this paper, assumes implicitly that changes in male density affect the females' demography in the same way as females affect their own demography. For simplicity, a homogeneous population is further assumed; i.e., we consider average female individuals of which some are reproductively active, and some are not.

The start of the reproductive season will be delayed for some length of time depending on density due to the process of establishing territories of the overwintered females (e.g., Bujalska, 1970, 1981, 1983a; Wiger 1979, 1982). Similarly, after delivery of a litter, a female may - if density is low - become pregnant immediately, or - if the density of females is high - there will be a period between delivery of a litter and the subsequent pregnancy (Bujalska, 1970, 1983a; Wiger, $1979,1982)$. 
Let $T_{l, 1}$ be the length of time between the earliest possible day of becoming pregnant and the actual delivery of the first litter. Similarly, $T_{l, 2}$ is the length of time between the delivery of the first and second litters. Generally, $T_{l}, i$ is the length of time between the $(i-1)^{t h}$ and the $i^{\text {th }}$ litter.

I have used the following formula for describing $T_{l},{ }_{i}=T_{l}\left(x_{i-1}\right)$, where $x_{i-1}$ is the total density of females at the time of the $(i-1)^{\text {th }}$ delivery (for $i=1, x_{i-1}$ is the total number of overwintering females in the population):

$$
T_{l,}=T_{l}\left(x_{i-1}\right)=g+k_{1} \cdot g \cdot x_{i-1}\left(h+x_{l-1}\right)
$$

where $g$ is the shortest possible length of time between litters (i.e., the length of the gestation period) and $h$ measures the density dependence of $T_{l}$ (see Fig. 2). The standard case of the model applies $g=16$ (e.g., Wrangel, 1940) and $k_{1}=1$. (Notice that a gestation period equal to 16

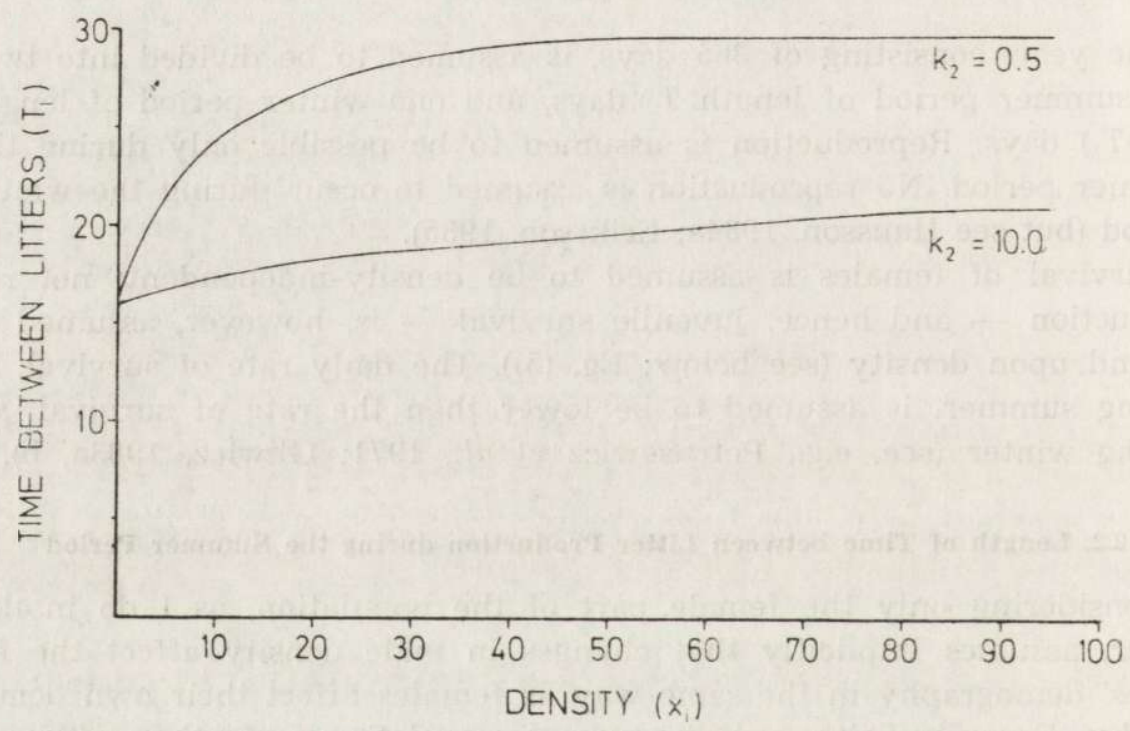

Fig. 2. The assumed relation between between-litter interval, $T$, and the total density of females, $x_{i}$.

days may be somewhat too short as, e.g., Bujalska \& Ryszkowski (1966) found a gestation period of 22 days. This will, however, have no effect on the qualitative conclusions to be drawn in this study). The parameter defining the degree of density dependence in $T_{l}, h$, is easier to interpret if it is related to the total female density for which no female will be mature, $x_{m}$ (defined precisely below; see Eq. (5)) (Bujalska, 1985). Hence, we assume

$$
h=k_{2} \cdot x_{m}
$$


where $k_{2}$ is a positive parameter; high values of $k_{2}$ imply a more slowly increasing time-interval between successive litters with increasing density.

The number of litters being produced during the summer season is then given by $n_{\max }$ defined as

$$
n_{\max }=\max n \text { so that } \sum_{i=0}^{n-1} T_{l}\left(x_{i}\right) \leqslant T_{s} .
$$

\subsection{Proportion of Females being Mature (Territorial)}

Let $p=p\left(x_{i}\right)$ be the fraction of mature (i.e., territorial) females in a population of density $x_{i}$. The fraction of mature females in the pop-

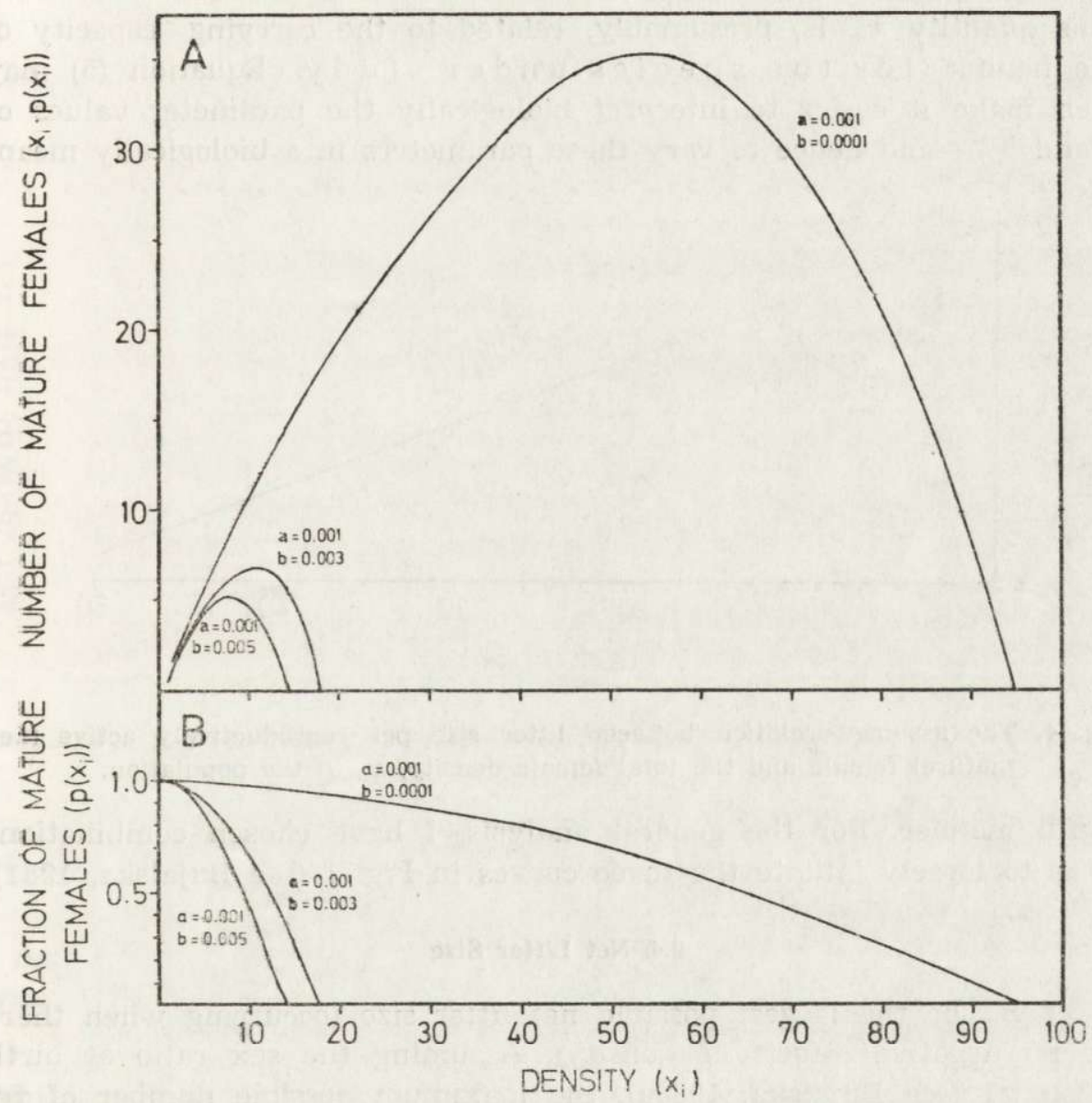

Fig. 3. Three curves, corresponding to those depicted in Fig. 1. (A) depicts the $p\left(x_{i}\right)$-curves whereas (B) depicts the $x_{i} p\left(x_{i}\right)$-curves, the latter corresponds directly to those depicted in Fig. 1. 
ulation will, because of territoriality, be a decreasing function of total density in the population; such a relation was reported by Bujalska (1981) (see Fig. 3). For the general analysis, I have assumed the following formula for $p\left(x_{i}\right)$ (but see Sect. 3.2. below):

$$
p\left(x_{i}\right)=\left\{\begin{array}{l}
1-a \cdot x_{i}-b \cdot x_{i}^{2}>0 \\
0 \quad \text { otherwise. }
\end{array}\right.
$$

As can be seen, all females are assumed to be mature at very low female densities (i.e., $p(0)=1$ ).

Let $x_{m}$ be the lowest female density for which $p$ is equal to zero; this quantity may then be found as

$$
x_{m}=-a /(2 \cdot b)+\left((a /(2 \cdot b))^{2}+1 / b\right)^{1 / 2} .
$$

This quantity $x_{m}$ is, presumably, related to the carrying capacity of the habitat for the species under study. Equation (5) may then make it easier to interpret biologically the parameter values of $a$ and $b$ - and hence to vary these parameters in a biologically mean-

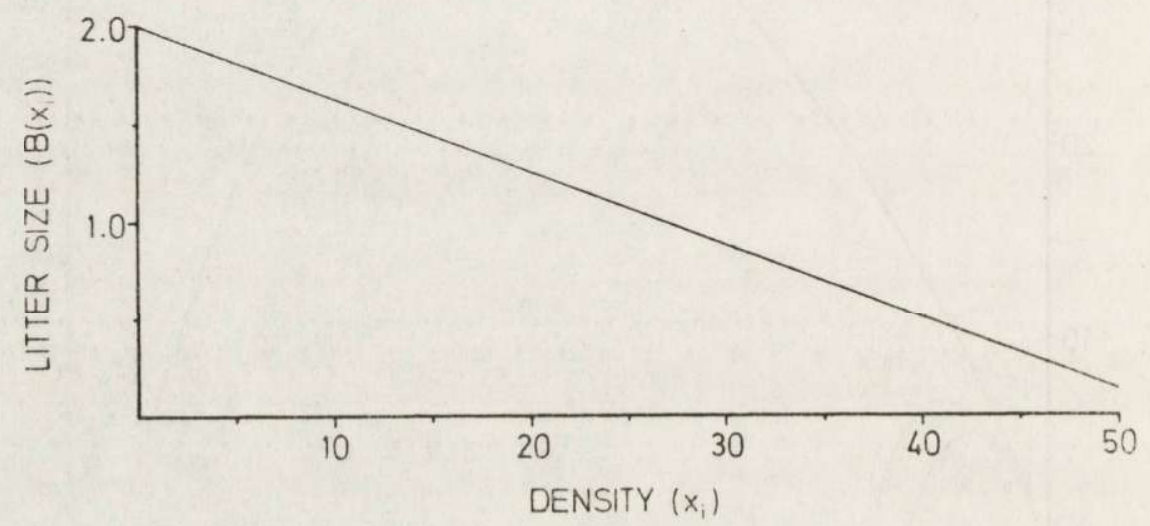

Fig. 4. The assumed relation between litter size per reproductively active (i.e., mature) female and the total female density, $x_{i}$, in the population.

ingful manner. For the general analysis, I have chosen combinations so as to loosely imitate the three curves in Fig. 1 (see Bujalska, 1981).

\subsection{Net Litter Size}

Let $B_{m}$ be the largest possible net litter size (occurring when there are no negative effects of density). Assuming the sex ratio at birth to be $1: 1$ (see Bujalska, 1983a), the maximum possible number of febales being recruited to the population is given by $0.5 \cdot B_{m}$. Let $B\left(x_{i}\right)$ be the net recruitment of females conceived at a female density $x_{i}$. This $B$-function is defined as 


$$
B\left(x_{i}\right)= \begin{cases}0.5 \cdot B_{m}\left(1-x_{i} /\left(k_{3} \cdot x_{m}\right)\right)>0 \\ 0 & \text { otherwise, }\end{cases}
$$

where $k_{3}$ is a positive parameter determining the degree of density dependence (Fig. 4). Notice that the $B\left(x_{i}\right)$ includes the litter size as foetal and suckling mortality.

\subsection{Components of Population Growth}

Since we only consider an average female, we may describe the population dynamics within a season by a discrete time population dynamic model. Let $r_{i}$ be the net rate of growth in a population of initial female density equal to $x_{i}$; this is defined as

$$
r_{i}=\left(b\left(x_{i}\right) \cdot p\left(x_{i}\right)+1\right) \cdot s_{s}{ }^{T} l\left({ }^{x}\right) i
$$

where $s_{s}$ is the daily survival rate during the summer (Fig. 5). Then,

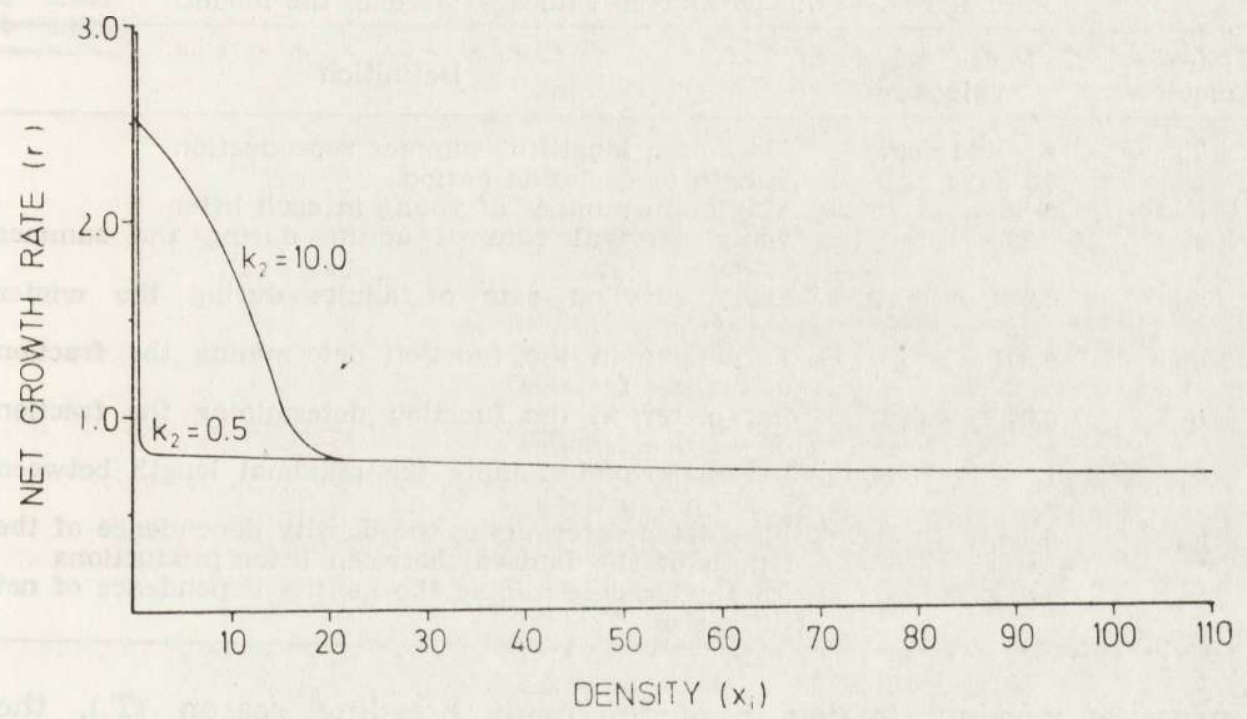

Fig. 5. Net growth rate $r_{i}$, between successive cohorts as a function of density, $x_{i}$; the curves assume $a=0.001 \& b=0.003$.

a recursive population growth model for the withinseason population dynamics is given by

$$
x_{i+1}=r_{i} \cdot x_{i} \text {. }
$$

Similarly, the total survival during the non-reproductive winter season is given by $s_{w}{ }^{365-T} s$, where $s_{w}$ is the daily survival rate during winter. In order to complete the cycle, we also have to adjust for mortality during the spring period of territorial establishment and the fall pe- 
riod after the last litter has been produced but before winter starts. Hence, we need to multiply the fall density by $s_{s}{ }^{T}{ }^{-T_{s}}$ where

$$
T_{r}=\sum_{i=1}^{n-1} r^{n} \cdot\left(x_{i}\right)
$$

.(where $n=n_{\max }$; see Eq. (3)).

\section{RESULTS AND DISCUSSION}

\subsection{General Version}

I have investigated the dynamic behaviour of the model through numerical studies (see Appendix). The parameter values used in the analyses are summarized in Table 1 . I have concentrated on studying the

Table 1

Parameters - and parameter values - used in the model.

\begin{tabular}{|c|c|c|}
\hline $\begin{array}{l}\text { Para- } \\
\text { meter }\end{array}$ & $\begin{array}{l}\text { Parameter } \\
\text { values }\end{array}$ & Definition \\
\hline$T_{s}$ & $80-160$ days & Maximum length of summer reproduction \\
\hline$\stackrel{g}{B_{m}}$ & $\begin{array}{l}16 \text { days } \\
2-8\end{array}$ & $\begin{array}{l}\text { Length of gestation period } \\
\text { Maximum number of young in each litter }\end{array}$ \\
\hline $\boldsymbol{s}_{s}$ & 0.990 & $\begin{array}{l}\text { Maximum number of young in each litter } \\
\text { Daily survival rate of adults during the summer }\end{array}$ \\
\hline $\boldsymbol{s}_{w}$ & 0.999 & $\begin{array}{l}\text { Daily survival rate of adults during the winter } \\
\text { season }\end{array}$ \\
\hline$a$ & 0.001 & $\begin{array}{l}\text { Parameter in the function determining the fraction } \\
\text { of mature females }\end{array}$ \\
\hline$b$ & $0.0001-0.005$ & $\begin{array}{l}\text { Parameter in the function determining the fraction } \\
\text { of mature females }\end{array}$ \\
\hline$k$, & 1 & $\begin{array}{l}\text { Parameter determining the maximal length between } \\
\text { litter productions }\end{array}$ \\
\hline$k_{0}$ & $0.5-10$ & $\begin{array}{l}\text { Parameter determining the density dependence of the } \\
\text { length of the interval between litter productions }\end{array}$ \\
\hline$k_{2}$ & 3.0 & $\begin{array}{l}\text { Parameter determining the density dependence of net } \\
\text { litter size }\end{array}$ \\
\hline
\end{tabular}

effect of varying the length of the main breeding season $\left(T_{s}\right)$, the maximum possible litter size $\left(B_{m}\right)$, and the density dependence $\left(k_{2}\right)$ in the time between successive litters (see Eq. (1)).

The results of these numerical studies are summarized in Table 2. As can be seen, there are no dramatic differences with respect to overall stability properties between the three cases represented by the three curves depicted in Fig. 1: all cases seem, in general, to correspond to rather stable population dynamics. Only a few parameter combinations seem to cause instability (and hence, possibly cycles). Notice that high litter sizes, short potential summers and/or high carrying capacity ( $x_{m}$; see Eq. (5)) (i.e., the lower case in Table 2) in particular seem to 
destabilize the density. This corresponds directly to the result derived by Stenseth \& Fagerström (1985) on the basis of a far more complicated model. This concordance certainly strengthens the validity of the conclusions reached by Stenseth \& Fagerström (1985).

\section{Table 2}

Survey of the stability-properties of the model for various combinations of values of three critical parameters, the potential length of the summer period $\left(T_{s}\right)$, the maximal litter size $\left(B_{m}\right)$ and the degree of density dependence $\left(k_{s}\right)$ in the time between successive litters. Number given in the table are percentages of cases for which a cyclic population dynamic pattern results. $a$ and $b$ are defined in Table 1 and the text.

\begin{tabular}{|c|c|c|c|c|c|c|c|c|c|}
\hline \multirow{2}{*}{$\begin{array}{c}\text { Case } \\
(a \& b)\end{array}$} & \multicolumn{3}{|c|}{$T_{s}$} & \multicolumn{3}{|c|}{$B_{m}$} & \multicolumn{2}{|c|}{$k_{2}$} & \multirow[b]{2}{*}{ Avg } \\
\hline & 80 & 120 & 160 & 2 & 4 & 8 & 0.5 & 10.0 & \\
\hline $\begin{array}{l}a=0.001 \\
b=0.005\end{array}$ & 33 & 0 & 0 & 0 & 0 & 33 & 11 & 11 & 11 \\
\hline $\begin{array}{l}a=0.001 \\
b=0.003\end{array}$ & 30 & 17 & 17 & 0 & 0 & 67 & 11 & 33 & 22 \\
\hline $\begin{array}{l}a=0.001 \\
b=0.0001\end{array}$ & 33 & 17 & 17 & 0 & 0 & 67 & 11 & 33 & 22 \\
\hline
\end{tabular}

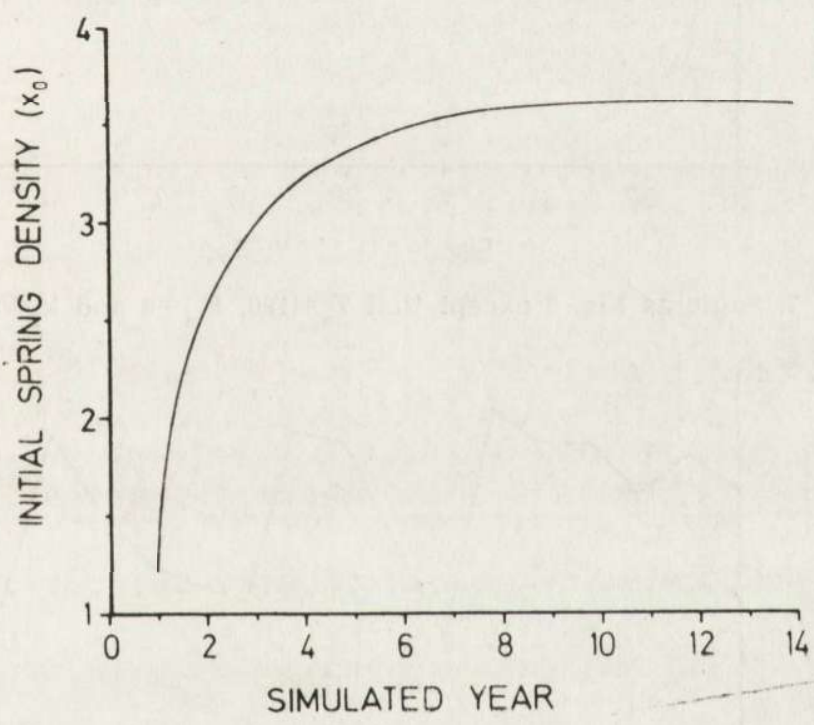

Fig. 6. An example of a parameter set-up resulting in stable dynamics (that is, the most typical pattern emerging from this model). Parameters are $T_{s}=\mathbf{8 0}, g=16$, $B_{m}=2, a=0.001, b=0.003$ and $k_{3}=0.5$; other parameter values are as shown in Table 1.

In Fig. 6-8 I have depicted some examples of the resulting population dynamics: figure 6 depicts a typical stable population - most cases are like this. Figures 7 and 8 depict some of the unstable population dynamics patterns. 
I have further analyzed the model by evaluating the index for cyclicity proposed by Stenseth (1977) (see also Stenseth \& Framstad, 1980; Henttonen et al., 1985) given as

$$
\varrho=\left(\operatorname{var}\left(\log _{10}\left(\mathrm{~N}_{\mathrm{t}}\right)\right)\right)^{1 / 2}
$$

where $N_{t}$ is the initial spring density in year $t$. The index has been estimated on the basis of the simulated densities from year 20 to 50

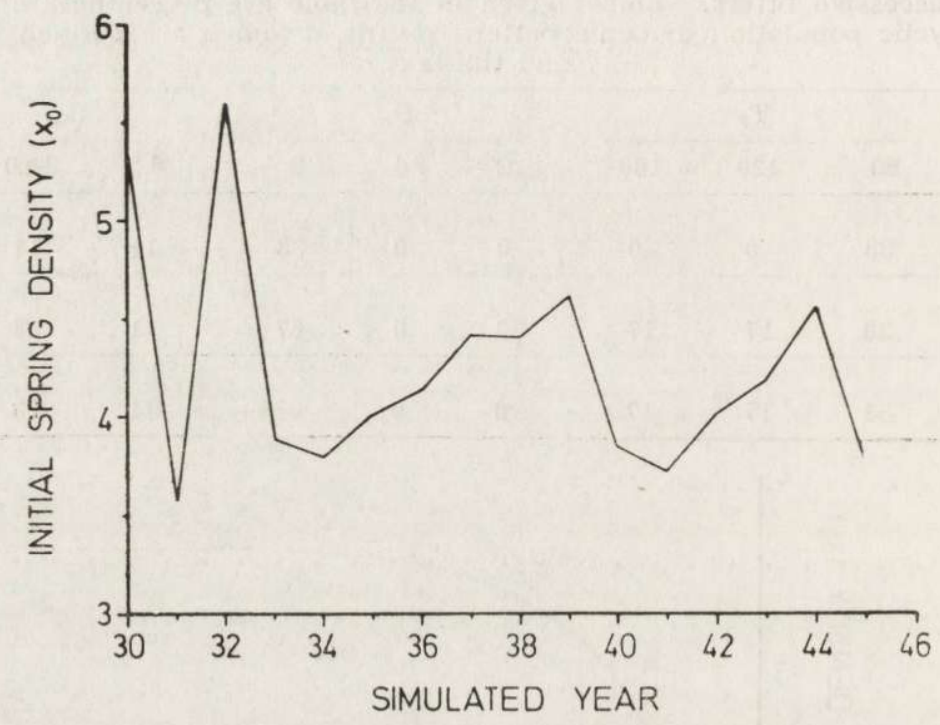

Fig. 7. Same as Fig. 5 except that $T_{s}=120, B_{m}=8$ and $k_{2}=10$.

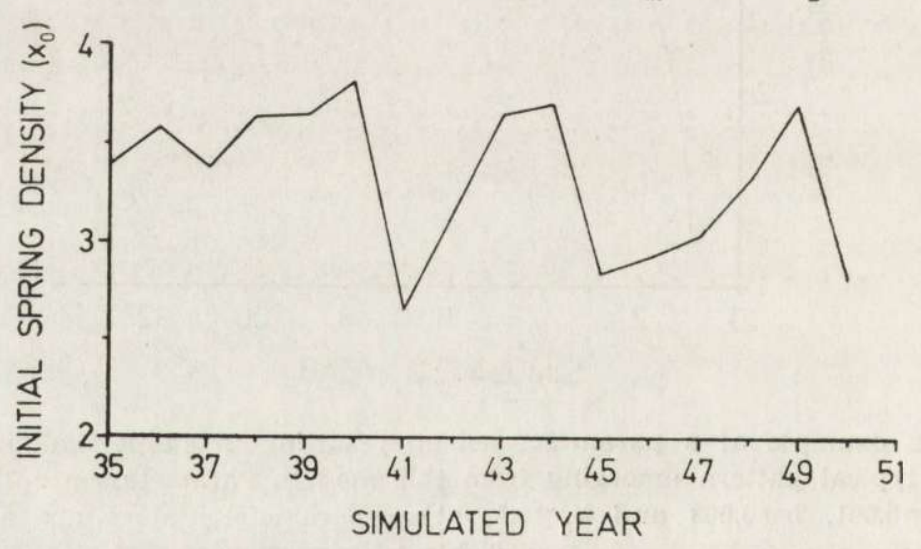

Fig. 8. Same as Fig. 6 except that $T_{s}=160$.

for all combinations of parameters in Table 1. The dependence between the value of the $\varrho$-index and these parameter values are reported in Table 3. As can be seen, increased reproductive rate tends to destabilize the population dynamics. Furthermore, decreasing value of $b$ tends to 
destabilize the population dynamics; however, since decreasing value of $b$ implies increasing value of $x_{m}$ - the carrying capacity - the analysis suggests that increasing productivity of the region tends to destabilize the population dynamics of the voles. Finally we see a weak tendency for increased length of the summer period to stabilize the population dynamics, whereas decreased density dependence in inter-birth interval tends to stabilize the population dynamics. Again this resembles the results obtained by Stenseth \& Fagerström (1985) on the basis of a much more complicated model.

It is possible to understand the obtained results on the basis of general population dynamics theory. As is well known, too strong density dependence in a seasonal environment (e.g., Maynard Smith, 1968, 1974; May, 1981; see also Stenseth \& Antonsen, 1985) may often lead to violent density oscillations; this is particularly so in regions with high

Table 3

Dependence between the cyclicity index, $\varrho$, and the various parameters of the model. Symbol interpretation: + denotes a significant positive correlation between $\rho$ and the respective parameter; - denotes a significant negative correlation between $\varrho$ and the parameter; $(+)$ and $(-)$ denote weak trends which were not significant.

\begin{tabular}{lllr}
\hline \multicolumn{4}{c}{ Parameter } \\
\hline$T_{s}$ & $B$ & $b$ & $k_{2}$ \\
\hline$(-)$ & + & - & $(+)$ \\
\hline
\end{tabular}

reproductive intensity and high equilibrium densities (i.e., carrying capasities). This is also the reason for the density fluctuations seen in the present model because both decreased length of summer period and increased density dependence in inter-birth interval lead to greater percentage variation in $n_{\max }$ (see Eq. (3)) - and hence, greater density dependence in $n_{\max }$.

\subsection{Clethrionomys glareolus and Apodemus agrarius}

I have also analyzed the model for the particular populations of Clethrionomys glareolus and Apodemus agrarius discussed by Bujalska (1981): specifically, I have used the empirically derived $p$-functions (see Eq. (4)) provided by Bujalska (1984; pers. comm.).

The Clethrionomys-curve provided by Bujalska is defined by

$$
\left[p\left(x_{i}\right)\right]^{2}=-0.0738+35.91 \cdot x^{-1}-840.63 \cdot x^{-2}
$$

for $0 \leqslant p\left(x_{i}\right) \leqslant 1$; if $p\left(x_{i}\right)$ given by Eq. (11) is greater than one, $p\left(x_{i}\right)$ is assumed equal to 1 , and if $p\left(x_{i}\right)$ given by Eq. (11) is less than zero, $p\left(x_{i}\right)$ is assumed equal to 0. 
Using $g=22$ (see Eq. (1)), $p\left(x_{i}\right)$ defined by Eq. (11) and all other functions as defined above, analysis for the spectrum of parameter values given in Table 1 demonstrated that the resulting population dynamics always are very stable. Analysis of the kind reported in Table 3 for the general model, demonstrated a comparable pattern except that $\mathrm{T}_{\mathrm{s}}$ has a more pronounced effect in the specific model for Clethrionomys glareolus.

The population dynamics of the Clethrionomys glareolus population studied by Bujalska and others are indeed expected to be $\mathrm{stable}$ because of the sexual inhibition of non-territorial females. My analysis of the data provided by Bujalska does indeed suggest the validity of Bujalska's (1970) hypothesis; this is particularly the case when comparing the results reported in this section with those reported in Section 3.1.

The Apodemus-curve provided by Bujalska is defined by

$$
p\left(x_{i}\right)= \begin{cases}0.553-0.00455 \cdot x-0.818 \cdot & x^{-1}>0 \\ 0 & \text { otherwise. }\end{cases}
$$

When using $p\left(x_{i}\right)$ defined by Eq. (12) and all other functions as defined above, fairly stable population dynamics result for most of the parameter-combinations given in Table 1 . The pattern which emerged from the analysis of the general model (see Section 3.1.) is, in fact, very similar to the pattern emerging from the Clethrionomys-model defined by Eq. (11). As in the general analysis, increasing length of the summer period tends to stabilize the population dynamics whereas increased density dependence in the inter-birth interval tends to destabilize the population dynamics.

\subsection{A Technical Note}

It should be noticed that the structure of the discussed model is a difference equation model with a variable time step. The length of the time step is determined by the density of the population: the higher density, the longer time steps. Biologically this is a fairly reasonable way of describing the population dynamics of Clethrionomys - like populations. Unfortunately there exist no standard mathematical techniques for carrying out an ordinary stability analysis of such models. Such techniques are in fact badly needed.

However, since I felt it more important to incorporate the variable time step than to perform some sort of standard stability analysis, I had to rely on numerical studies. Such numerical studies always have several shortcomings. It is clear, however, that one of the main results derived in this paper would not have been detected if I had paid more attention to mathematical elegance than to biological reality. 


\section{CONCLUSION}

On the basis of this analysis, it seems clear that the social system of exclusive female territoriality, observed in all populations of all Clethrionomys species (e.g., Bujalska, 1983a; Rajska-Jurgiel, 1976; Gliwicz \& Rajska-Jurgiel, 1983), in general leads to stable population densities. If species which are characterized by inhibition of females' sexual maturation at high densities also are cyclic, another factor must be responsible for the cyclicity. Then, if Clethrionomys species are cyclic, this must be due to some stronger overriding destabilizing factors such as for example, seasonality (discussed in this paper and by Stenseth \& Fagerström (1985)) and various trophic interactions (see, e.g., discussion in Stenseth (1985)). It thus seems more important than ever to carry out detailed comparative studies of stable and cyclic populations of Clethrionomys species. The bank vole, C. glareolus, seems well suited for this purpose: this species has both stable and cyclic populations, both of which are rather well studied (see, e.g., Petrusewicz (ed.), 1983; Hansson, 1984b). If we could understand why some of these populations are cyclic, we might be able to understand why, for example, Microtus in general seems to be far more cyclic than Clethrionomys: hence, we may be able to understand the general differences in cyclicity between small rodent species (see, e.g., Krebs, 1979: 76).

Compared to other microtines, Clethrionomys seems far better suited for studying why some species are cyclic whereas others are not because of its fairly uniform social system. We should not miss this opportunity to study the emerging population dynamic consequences of social organization (like, e.g., female territoriality). We are now at a stage where theoretical studies (like the present one) may go hand-inhand with empirical studies in the field (see, eg., Petrusewicz (ed.), 1983) and laboratory (e.g., Gustafsson, 1985). The model discussed in this paper may, in fact, serve as a total for interpreting the population dynamic consequences of findings in the field and in the laboratory: as exemplified in Section 3.2, empirically obtained forms of the various functions entering the model may be used in the analysis of the model.

To continue the Clethrionomys-studies along these lines would, I am sure, be in the spirit of the late Professor K. Petrusewicz.

Acknowledgements: Beside Kazimierz Petrusewicz, Gabriela Bujalska and Joanna Gliwicz have taught me a lot about microtine biology in general and Clethrionomys biology in particular. Torgny Gustafsson, Søren Bondrup-Nielsen and Rolf Anker Ims have also taught me much about Clethrionomys biology. Søren Bondrup-Nielsen, Gabriela Bujalska and Joanna Gliwicz are thanked for commenting on an earlier version of this paper. Fred Roger Horndal is thanked for great help with the numerical analysis of the model. 


\section{REFERENCES}

1. Bujalska G., 1970: Reproduction stabilizing elements in an island population of Clethrionomys glareolus (Schreber, 1780). Acta theriol., 15: 381-412.

2. Bujalska G., 1981: Reproduction strategies in populations of Microtus arvalis (Pall.) and Apodemus agrarius (Pall.) in habiting farmland. Polish ecol. Stud., 7: 229-243.

3. Bujalska G., 1983a: Sex ratio. [In: "Ecology of the bank vole", ed. K. Petrusewicz]. Acta theriol., 28, Suppl. 1: 103-111.

4. Bujalska G., 1983b: Reproduction. [In: "Ecology of the bank vole", ed. K. Petrusewicz]. Acta theriol., 28, Suppl. 1: 148-161.

5. Bujalska G., 1984: Sex ratio and structure of a population of Clethrionomys glareolus. Acta Zool. Fenn. (in press.)

6. Bujalska G., 1985: Regulation of female maturation in Clethrionomys species with special reference to an island population of C. glareolus. Ann. Zool. Fenn., 22: $331-342$.

7. Bujalska G. \& Ryszkowski L., 1966: Estimation of the reproduction of the bank vole under field conditions. Acta theriol., 11: $351-361$.

8. Eriksson M., 1985: Winter breeding in three rodent species, the bank vole (Clethrionomys glareolus), the yellow-necked mouse (Apodemus flavicollis), and the wood mouse (Apodemus sylvaticus) in southern Sweden. Holarctic Ecol. (in press.)

9. Gipps J. H. W., 1985: Spacing behaviour and male reproductive ecology in Voles of the genus Clethrionomys. Ann. Zool. Fenn., 22: 343-351.

10. Gliwicz J., 1983a: Age structure. [In: "Ecology of the bank vole", ed. K. Petrusewicz]. Acta theriol., 28, Suppl. 1: 111-117.

11. Gliwicz J. 1983b: Survival and life span. [In: "Ecology of the bank vole", ed. K. Petrusewicz]. Acta theriol., 28, Suppl. 1: 161-172.

12. Gliwicz J. \& Rajska-Jurgiel E., 1983: Social organization. [In: "Ecology of the bank vole", ed. K. Petrusewicz]. Acta theriol., 28, Suppl. 1: 134-140.

13. Gliwicz J., Andrzejewski R., Bujalska G. \& Petrusewicz K., 1968: Productivity investigations of an island population of Clethrionomys glareolus (Schreber, 1780). I. Dynamics cohorts. Acta theriol., 13: $401-413$.

14. Gustafsson T. O., 1985: Sexual maturation in Clethrionomys. Ann. Zool. Fenn., 22: $303-308$.

14a. Hansson L., 1984a: Winter reproduction of small mammals in relation to food conditions and population dynamics. [In: "Winter ecology of small mammals", ed. J. F. Merritt]. Carnegie Mus. Nat. Hist. Spec. Publ., 10: 225-234. Pittsburgh.

15. Hansson L., 1984b: Composition of cyclic and non-cyclic vole population: on the causes of variation in individual quality among Clethrionomys glareolus in Sweden. Oecologia, 63: 199-206.

16. Henttonen H., McGuire A. D. \& Hansson L., 1985: Comparisons of amplitudes and frequencies (spectral analyses) of density variation in long-term data sets of Clethrionomys species. Ann. Zool. Fenn., 22: 221-227.

17. May R. M., 1981: Models for single populations. [In: "Theoretical ecology", ed. R. M. May]. Blackwell Scient. Publ.: 5-29, Oxford.

18. Maynard Smith J., 1968: Mathematical ideas in biology. Camb. Univ. Press: Cambridge.

19. Maynard Smith J., 1974: Models in ecology. Camb. Univ. Press: Cambridge.

20. Krebs C. I., 1979: Dispersal, spacing behaviour, and genetics in relation to population fluctuations in the vole Microtus townsendii. Fortschr. Zool., 25: 
$61-77$.

21. Petrusewicz K. (ed.), 1983: Ecology of the bank vole. Acta theriol., 28, Suppl. 1: $1-242$.

22. Petrusewicz K., 1983: Patterns of population dynamics. [In: "Ecology of the bank vole", ed. K. Petrusewicz]. Acta theriol., 28, Suppl. 1: 145-148.

23. Petrusewicz K., Bujalska G., Andrzejewski R. \& Gliwicz J., 1971: Productivity processes in an island population of Clethrionomys glareolus. Ann. Zool. Fenn., 8: $127-132$.

24. Rajska-Jurgiel E., 1976: Interactions between individuals of the bank vole, Clethrionomys glareolus (Schreber, 1780). Ekol. pol. A, 24: 3-35.

25. Stenseth N. C., 1977: Theoretical studies on fluctuating populations: an evolutionary approach. Unpubl. Doctoral Thesis, Univ. of Oslo.

26. Stenseth N. C., 1985: On the interaction between stabilizing social factors and destabilizing trophic factors in small rodent populations. Theor. pop. Biol. (in press).

27. Stenseth N. C. \& Antonsen B., 1985: Density dependence and the microtine cycle (I): a continuous time model with delay due to development. Oikos (in review).

28. Stenseth N. C. \& Fagerström T., 1985: Population density regulation in Clethrionomys: the effect of changing litter size and length of reproductive season. Acta theriol. (in review).

29. Stenseth N. C. \& Framstad E., 1980: Reproductive effort and optimal reproductive rates in small rodents. Oikos, $34: 23-34$.

30. Stenseth N. C., Bondrup-Nielsen S. \& Ims R. A., 1985a: A population dynamics model for Clethrionomys; sexual maturation, spacing behaviour and dispersal. Oikos (in press).

31. Stenseth N. C., Gustafsson T. O., Hansson L. \& Ugland K. I., 1985b: On the evolution of reproductive rates in microtine rodents. Ecology, 66: 1795-1805.

32. Wiger R., 1979: Demography of a cycling population of the bank vole, Clethrionomys glareolus. Oikos, 33: 373-385.

33. Wiger R., 1982: Roles of self-regulatory mechanisms in cyclic populations of Clethrionomys with special reference to C. glareolus: a hypothesis. Oikos, 38: $60-71$.

34. Wrangel H., 1940: Beiträge zur Biologie inbesondere der Fortpflanzungsbiologie der Rötelmaus, Clethrionomys glareolus (Schreber, 1780). Z. Säugetierk., 14: $52-93$.

Accepted, May 15, 1985. 
APPENDIX: The FORTRAN program used for analyzing the model

In order to make it easier to carry out further analysis of the model, I present a copy of the program here: only the central parts of the program defining the functions are given. Whoever is to use this program must write his or hers FORTRAN statements for reading in parameter values and writing out output results.

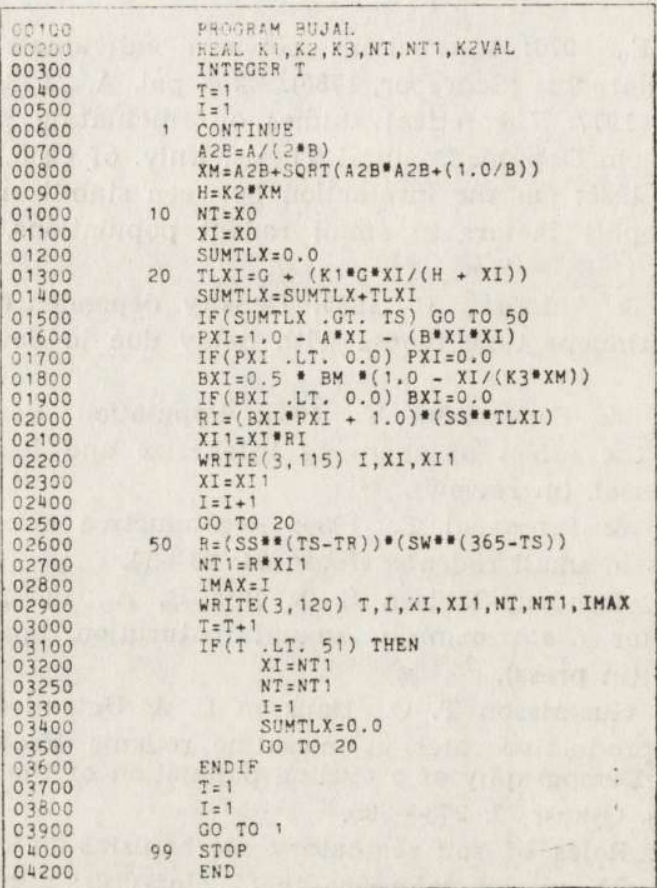

Nils Chr. STENSETH

\section{ZNACZENIE TERYTORIALIZMU SAMIC DLA DYNAMIKI POPULACJI NORNICY RUDEJ}

\section{Streszczenie}

Wykorzystując dane literaturowe, autor skonstruował i poddal analizie model zmian dynamiki populacji nornicy rudej (Tabela 1). Model ten opiera się na fakcie, iż wysoka liczba mających tendencje terytorialne dojrzałych samic, wywoluje zahamowania rozrodu $u$ młodych samic (Ryc. 1). Szczególnie odbija się to na wielkości miotu i wydłużaniu się okresów między kolejnymi miotami (Ryc. 2). Do konstrukcji modelu włączono również sezonowość, z uwagi na założenie, że rozród odbywa się wyłącznie w okresie lata (Tabela 2, 3). Analiza modelu wykazała, że terytorializm samic jest bardzo ważnym czynnikiem (Ryc. 3-8). Krótki, letni sezon rozrodczy i duże mioty mogą jednakże destabilizować tę populację. 